\title{
GAS CHROMATOGRAPHY-MASS SPECTROMETRY ANALYSIS, IN VITRO CYTOTOXIC AND ANTIOXIDANT EFFICACY STUDIES ON CLEOME GYNANDRA L. (LEAVES): A TRADITIONAL DRUG SOURCE
}

\author{
RENUKA SARAVANAN ${ }^{1}$, BRINDHA PEMAIAH ${ }^{2}$, MAHESH NARAYANAN ${ }^{1}$, SIVAKUMAR RAMALINGAM ${ }^{1 *}$
}

${ }^{1}$ Department of Chemistry \& Biosciences, SRC, SASTRA University, Kumbakonam - 612 001, Tamil Nadu, India. ${ }^{2}$ Centre for Advanced Research in Indian System of Medicine, SASTRA University, Thanjavur, Tamil Nadu, India. Email: rsiva@src.sastra.edu

Received: April 22, 2017, Revised and Accepted: May 27, 2017

\section{ABSTRACT}

Objective: This study was aimed to assess the phytoconstituents, cytotoxic, and antioxidant efficacy of ethyl extract of Cleome gynandra leaves.

Methods: Qualitative phytochemical analysis with different solvent extracts was performed. Quantitative and gas chromatography-mass spectrometry (GC-MS) analysis of the extract was performed with ethyl acetate extract. The cytotoxic effect of the ethyl acetate extract was determined by 3-[4,5-dimethylthiazol-2-yl]2,5-diphenyltetrazolium bromide (MTT) assay on Michigan Cancer Foundation-7 (MCF-7) cells using taxol as standard and free radical scavenging ability using 1,1-diphenyl-2-picrylhydrazyl (DPPH).

Results: Leaves extracts with different solvents revealed the presence of alkaloids, cardiac glycosides, flavonoids, phenols, and tannins. GC-MS analysis of ethyl acetate of the plant leaves showed the presence of $\mathrm{n}$-hexadecanoic acid. The $\mathrm{IC}_{50}$ value of the ethyl acetate extract was found to be $90.2 \mu \mathrm{g} / \mathrm{ml}$ on MCF-7 cell line, and the extract was found to possess significant DPPH free radical scavenging activity.

Conclusion: From the results, we conclude that the C. gynandra extract possesses antioxidant and antiproliferating activity against MCF-7 cells.

Keywords: Anticancer, Cleome gynandra, Palmitic acid, Phytol, phenol, 1,1-diphenyl-2-picrylhydrazyl and 3-[4,5-dimethylthiazol-2-yl]2,5diphenyltetrazolium bromide.

(c) 2017 The Authors. Published by Innovare Academic Sciences Pvt Ltd. This is an open access article under the CC BY license (http://creativecommons. org/licenses/by/4. 0/) DOI: http://dx.doi.org/10.22159/ajpcr.2017.v10i10.19343

\section{INTRODUCTION}

Cancer is one of the major threats, which is characterized by proliferation of abnormal cells [1]. Chemotherapy is still counted as an important component of cancer therapy, though there are other advances in this therapy. At present, 90\% drug failures in metastatic cancers can be attributed to chemoresistance [2]. Mounting evidence has documented two major chemoresistance mechanisms in various human cancers, namely, de novo (intrinsic) that refers to cancer cells being resistant to chemotherapeutic drugs from the beginning of the treatment, and acquired (extrinsic) due to genetic and epigenetic alteration of crucial genes in cancer during repetitive chemotherapy [3]. Hence, there is a need to understand the mechanism of chemoresistance by developing novel therapeutic approach to treat cancer.

Michigan Cancer Foundation-7 (MCF-7). It is the breast cancer cell line isolated in 1970 from 69 years old Caucasian woman. It is a malignant tumor that starts in the cells of the breast. It is found mostly in women. MCF7 cells have been extensively used as the model for breast cancer and breast cancer therapy [4].

Breast cancer is one of the most prevalent cancers among women worldwide. Chemotherapy generally leads to drug resistance and severe side effects thus making it crucial to identify and develop highly efficient chemotherapeutic agents [5]. Genetics plays a limited but important role as a risk factor for breast cancer. Only 5-6\% of breast cancers are considered hereditary. BRCA-1 and BRCA-2 account for an estimated $80 \%$ of hereditary breast cancer, but again, this only represents 5-6\% of all breast cancers. BRCA- 1 and/or BRCA2 positive women have a $50-85 \%$ lifetime risk of developing breast cancer, and $15-65 \%$ risk of developing ovarian cancer beginning at age $25[6]$.
Although modern medicine uses synthetic drugs as therapeutic agents, plants still play a prominent role in contemporary pharmacy, as sources of pharmaceutical drugs in the form of isolated molecules or as sources of precursors. It is, however, important to realize that despite the advancement in biomedicine, the progress afforded the residents of first world countries is beyond the reach of the majority of the world's population. The World Health Organization is actively promoting the development of traditional herbal medicines [7].

In the medical and pharmaceutical field, natural products are always rich source providers of new chemical units that enhance human health. Many commercialized drugs that help in the management of cancer are derived from natural sources through the process of modifying the structure or by semi-synthetic preparation. Hence, it becomes essential to develop novel anticancer drugs using improved cytotoxic agents which need to be discovered yet. The chemoresistance of the cancer cells has become a key issue, as there is a possibility of domination of the chemoresistant cells that may eventually lead to mortality. Due to this problem, there is a growing need to develop a new drug. Further, due to the cost effectiveness and less toxicity, herbal medicines as cancer therapeutic agents is gaining popularity among the present researchers. Clinically proven anticancer drugs such as camptothecin, taxol, vincristine and vinblastine are phytochemicals derived from plants. Conventional drugs used in the treatment of cancer are often linked with metastatic conditions which indicate a growing need for the discovery of more efficient new agents from phytogenic sources.

C. gynandra a plant with medicinal properties is distributed across the globe. It is common weed that could be spotted in paddy fields, open grass lands or along the roads. In India, it is a common weed and hence, never cultivated. Various species of the plant are found throughout India. Throughout the world, this plant is used to treat diseases ranging 
from epilepsy to some ordinary infections such as irritable bowel syndrome due to worm and protozoan infections. Due to its antioxidant properties and nutritional value, it is used in traditional culinary [8].

\section{Botanical description}

The selected plant is an erect herb with palmately compound leaves. The presence of glandular hair is a unique feature of this plant [9].

In ancient medicines, this plant is used as a rubefacient and antihelminthic. The leaves of the plant when applied externally on the wound prevent sepsis. The plant is known to cure common ailments such as malaria, piles, and rheumatism to serious problems like tumor. The decoction of the root is used in the treatment of fever and to relieve scorpion sting. The juice of the leaves is used as a remedy for earache [10].

C. gynandra possess enormous therapeutic potential including antitumor activity and is also safe and efficacious. This prompted us to study the antiproliferate and antioxidant activity of $C$. gynandra on MCF-7 cell lines, employing in vitro methods and attempts were also made to identify the compounds present in the extracts for the study using gas chromatography-mass spectrometry (GC-MS).

\section{METHODOLOGY AND PROCEDURE}

The whole plant sample was collected from Thanjavur, Tamil Nadu, and its adjoining areas. The sample is authenticated by comparing with the voucher specimen in the herbarium (Acc. No. RHT 172) available at Rapinat Herbarium, St. Joseph College, Tiruchirappalli, India. The leaves of the plant were processed by washing and drying in shade. Finally, the powdered leaves are extracted using ethyl acetate.

\section{Preparation of ethyl acetate extract}

About $50 \mathrm{~g}$ of the powder was soaked in ethyl acetate at room temperature for $72 \mathrm{hrs}$. It is then filtered through Whatman filter paper and concentrated to $1 / 8^{\text {th }}$ part and dried to get crude extract.

\section{Preliminary phytochemical screening}

The preliminary phytochemical screening was performed for various extracts according to methods [11]

\section{Quantitative analysis}

\section{Estimation of phenols}

Phenol was estimated by the method [12]. One gram of the powdered was extract weighed and ground with 10 -time volume of $80 \%$ ethanol. The supernatant was prepared by centrifuging the homogenate at $10,000 \mathrm{rpm}$ for 20 minutes. The supernatant obtained was dried by evaporation and the residue thus obtained was dissolved in $5 \mathrm{ml}$ distilled water. Different aliquots of the extract were pipetted out in test tubes and made up to $3 \mathrm{ml}$ with water. To the tubes, $0.5 \mathrm{ml}$ of Folin's reagent was added followed by the addition of $2 \mathrm{ml}$ of $20 \% \mathrm{Na}_{2} \mathrm{CO}_{3}$ and the contents were mixed well and placed in a boiling water bath for 1 minute. Then, the intensity is measured in a UV spectrophotometer at $650 \mathrm{~nm}$ with catechol as standard. The concentration of phenols was expressed as mg phenols/100 g material.

\section{Estimation of alkaloid}

Alkaloid was estimated by the method [13]. Using $0.1 \mathrm{~N} \mathrm{HCl}$, the plant powder was extracted. The aqueous acidified layer obtained was partitioned with chloroform using a separate funnel. The aqueous layer was basified with $\mathrm{NaOH}$ and partitioned with the chloroform layer was discarded. Then, the aqueous solution was partitioned with chloroform and the aqueous solution is discarded and the chloroform remaining was evaporated and the residue was treated as total alkaloid and confirmed with dragendorff's reagent. The residue was weighed, dried and calculated.

\section{Estimation of tannin}

Tannins were estimated by the method [14]. $2 \mathrm{~g}$ of the powder was defatted with petroleum ether for $12 \mathrm{hrs}$. The residue obtained was boiled with $300 \mathrm{ml}$ of double distilled water for 2 hrs. Cooled and diluted to $500 \mathrm{ml}$ and filtered. $25 \mathrm{ml}$ of this infusion was put into $2 \mathrm{~L}$ porcelain dish; added $20 \mathrm{ml}$ of indigo solution and $750 \mathrm{ml}$ of double distilled water. This was titrated against $0.1 \mathrm{~N} \mathrm{KMnO}_{4}$ solution, $1 \mathrm{ml}$ at a time, until blue solution changes to green. Thereafter, potassium permanganate solution was added drop by drop until solution becomes golden yellow in color. Similarly, the mixture of $20 \mathrm{ml}$ of indigo solution and $750 \mathrm{ml}$ of double distilled water was titrated. The difference between the titration in $\mathrm{ml}$ was calculated. Each $\mathrm{ml}$ of $0.1 \mathrm{~N}$ potassium permanganate solutions is equivalent to $0.004157 \mathrm{~g}$ of tannins.

\section{Estimation of saponins}

Saponin was estimated by the method [15]. In a conical flask, $20 \mathrm{~g}$ of the powder was taken and $100 \mathrm{ml}$ of $20 \%$ aqueous ethanol was added. The samples were heated over a hot water bath with constant stirring at $55^{\circ} \mathrm{C}$. After the mixture was filtered, the residue was re-extracted with $20 \%$ ethanol. Then, the combined residues were reduced to $40 \mathrm{ml}$ over a water bath at $90^{\circ} \mathrm{C}$. The concentrate was transferred into a $250 \mathrm{ml}$ separating funnel and $20 \mathrm{ml}$ of diethyl ether was added and shaken vigorously. The aqueous layer was recovered while the ether layer was discarded. The purification process was repeated. $60 \mathrm{ml}$ of n-butanol was added. The combined n-butanol extracts were washed twice with $10 \mathrm{ml}$ of $5 \%$ aqueous sodium chloride. The remaining solution was heated in a water bath. After evaporation, the samples were dried in an oven to a constant weight; the saponins content was calculated in percentage.

\section{Estimation of flavonoids}

Flavonoid was estimated by the method [16]. The plant powder was extracted with ethyl acetate. The extract was dried over anhydrous $\mathrm{NaSO}_{4}$, filtered and concentrated under vacuum up to a concentration of $1 \mathrm{~g} / \mathrm{ml}$ of extract. The extract was further diluted with ethyl acetate to obtain $0.01 \mathrm{~g} / \mathrm{ml}$ solution in the experiments. About $10 \mathrm{ml}$ of the solution was transferred into $25 \mathrm{ml}$ volumetric flask, $1 \mathrm{ml}$ of $2 \% \mathrm{AlCl}_{3}$ was added and the solution was filled up to the volume with methanolacetic acid and was kept aside for 30 minutes, the absorbance was measured at $390 \mathrm{~nm}$. A blank was also maintained. Luteolin was used to construct the calibration curve in the concentration of $1-10 \mu \mathrm{g} / \mathrm{ml}$.

\section{Antioxidant activity}

Radical Scavenging activity of 1,1-diphenyl-2-picrylhydrazyl (DPPH)

DPPH was performed by the method [17]. The DPPH assay was performed as per the ethyl acetate extracts of leaves of the plants dissolved in methanol, then $0.5 \mathrm{mM}$ DPPH solution in methanol was prepared and $0.5 \mathrm{ml}$ of this DPPH solution was mixed with $0.1 \mathrm{ml}$ of various amounts of the extract and mixed thoroughly, then $4 \mathrm{ml}$ of methanol was added and allowed to stand in a darkroom for $1 \mathrm{hr}$. The absorbance was measured at $516 \mathrm{~nm}$ in UV spectrophotometer (Perkin Elmer). Decrease in absorbance of the DPPH solution indicates an increase in DPPH radical scavenging activity. The DPPH scavenging of the plant activity was expressed as percentage of inhibition of the DPPH radicals.

\section{GC-MS analysis}

\section{Instruments and chromatographic conditions}

GC-MS analysis of ethyl acetate extract of C. gynandra was performed using the equipment PerkinElmer Clarus 500 GC-MS. The equipment ha Elite-5ms column $(30 \mathrm{~m} 0.25 \mathrm{~mm} 0.25 \mu \mathrm{m}$ film thickness, coated with $5 \%$ diphenyl-95\% dimethylpolysiloxane) interfaced with mass detector. Helium was used as carrier gas with a flow rate of $1 \mathrm{ml}$ per minute. Temperature program was $50-150^{\circ} \mathrm{C}$ hold for a few minute at the rate of $3^{\circ} \mathrm{C}$ per minute and increased to $290^{\circ} \mathrm{C}(10$ minute $)$ at the rate of $8^{\circ} \mathrm{C} /$ minute. The plant extract was dissolved in methanol and $1 \mu \mathrm{l}$ of the filtered methanol extract was injected with split ratio as 1:1. Mass spectra were recorded in the EI mode at $70 \mathrm{eV}$ in a scan range of 40-60. Injector and ion sources temperature were maintained at 280 
and $200^{\circ} \mathrm{C}$, respectively. The resulted spectra were compared with NIST library database [18].

\section{Cell line}

The human breast adenocarcinoma cell lines (MCF-7) were procured from National Centre for Cell Science, Pune, India, and grown in Eagle's minimal essential medium containing 10\% fetal bovine serum (FBS). The cells were maintained at $37^{\circ} \mathrm{C}$, with $5 \% \mathrm{CO}_{2}, 95 \%$ air and $100 \%$ relative humidity.

\section{Cytotoxic assay (in vitro)}

To make single cell suspension, the monolayers were detached using trypsin-EDTA. The viable cells were counted using hemocytometer. To get a final density of $1 \times 10^{5}$ cells $/ \mathrm{ml}$, the cells were suspended in $5 \%$ FBS medium. In a 96 well plate, wells were seeded with cell suspension of $100 \mu \mathrm{l}$ at a density of 10,000 cells per well. Then, incubated at $37^{\circ} \mathrm{C}$ for cell attachment with $5 \% \mathrm{CO}_{2}, 95 \%$ air $100 \%$ relative humidity. After $24 \mathrm{hr}$, the cells were treated with serial concentrations of the test samples; they were initially dissolved in dimethyl sulfoxide (DMSO). An aliquot of the sample solution was diluted to twice to get the desired final maximum test concentration with serum-free medium. Additional four serial dilutions were made to provide a total of five sample concentrations. Aliquots of $100 \mu \mathrm{l}$ of these different sample dilutions were added to the appropriate wells already containing $100 \mu \mathrm{l}$ of medium, resulting in the required final sample concentrations. Following sample addition, the plates were incubated for an additional $48 \mathrm{hr}$ with desired conditions. The medium without plant extract served as control and triplicates were maintained for all concentrations. $5 \mathrm{mg}$ of ethyl acetate extract was dissolved in $100 \mu \mathrm{L}$ of DMSO, and then diluted with culture media to get a series of concentration $(200,100$, 50,25 , and $12.5 \mu \mathrm{g} / \mathrm{ml}$ ). The culture media was used as negative control and taxol was used as positive control with the concentrations of 0.001 , $0.01,0.1,1$, and $10 \mu \mathrm{g} / \mathrm{ml}$. The assay was performed in triplicate [19].

Cytotoxic assay with 3-[4,5-dimethylthiazol-2-yl]2,5diphenyltetrazolium bromide] (MTT) method

MTT is a yellow water-soluble tetrazolium salt. A mitochondrial enzyme in living cells, succinate-dehydrogenase, cleaves the tetrazolium ring, converting the MTT to an insoluble purple formazan. Therefore, the amount of formazan produced is directly proportional to the number of viable cells.

After $48 \mathrm{hrs}$ of incubation, $15 \mu \mathrm{l}$ of MTT ( $5 \mathrm{mg} / \mathrm{ml}$ ) in phosphate buffered saline (PBS) was added to each well and incubated at $37^{\circ} \mathrm{C}$ for $4 \mathrm{hrs}$. The medium with MTT was then flicked off and the formed formazan crystals formed were solubilized in $100 \mu$ l of DMSO and absorbance was measured at $570 \mathrm{~nm}$ using microplate reader. The \% of cell inhibition was determined using the following formula:

$\%$ cell inhibition $=100-$ Abs $($ sample $) /$ Abs $($ control $) \times 100$

Nonlinear regression graph was plotted between \% cell inhibition and $\log$ concentration, and $\mathrm{IC}_{50}$ was determined using GraphPad Prism software [20].

\section{RESULT AND DISCUSSION}

Large scale screening of the crude plant extracts is a crucial and basic step to establish the efficacy in clinical application. Several reports show that plant crude extracts replicate at tumor sites under hypoxic conditions and stimulate the host immune response and gene expression and leads to the inhibition of tumor growth [21]. In this research, C. gynandra a common medicinal plant used in the treatment of tumor was selected and evaluated for its cytotoxic potential employing in vitro methods. Attempts were also made by employing GC-MS to identify the compounds present in the active fractions. Different extracts of C. gynandra leaves revealed the presence of alkaloids, flavonoids, steroids, tannins, cardiac glycosides, terpenoids, and phenols (Table 1).
The phytoconstituents present in the extract may be responsible for the various pharmacological actions of the plant although their specific roles remain to be unexplored. Quantitative analysis of the ethyl acetate extract of the plant was performed and the results obtained were presented in Table 2 .

From the quantitative analysis of phytoconstituents, we observed that the plant extract found to possess a significant amount of steroid, flavonoids, phenol and terpenoid and lesser amount of tannins, saponins, and alkaloids.

Data obtained in DPPH radical scavenging efficacy of $C$. gynandra leaves extract are presented in Fig. 1. The previous studies showed that ethyl acetate extract of $C$. gynandra found to possess antioxidant, anti-inflammatory, and lysosomal protection properties in adjuvant induced arthritic rats [22]. The antioxidant property of biomolecules, in particular, the plant extract is determined by its ability to scavenge DPPH radicals [23]. The results are expressed as an $\mathrm{IC}_{50}$ value (the amount of antioxidant necessary to decrease the initial DPPH concentration by

Table 1: Phytoconstituents in ethyl acetate extract of Cleome gynandra leaves

\begin{tabular}{lllll}
\hline Phytoconstituents & $\begin{array}{l}\text { Methanol } \\
\text { extract }\end{array}$ & $\begin{array}{l}\text { Aqueous } \\
\text { extract }\end{array}$ & $\begin{array}{l}\text { Chloroform } \\
\text { extract }\end{array}$ & $\begin{array}{l}\text { Ethyl } \\
\text { acetate } \\
\text { extract }\end{array}$ \\
\hline Alkaloids & - & - & - & + \\
Flavonoids & + & + & + & + \\
Tannins & + & + & + & + \\
Glycosides & - & + & + & - \\
Phenols & + & + & - & + \\
Saponins & + & + & + & + \\
Terpenoids & + & + & + & + \\
Carbohydrate & + & + & + & + \\
Protein & + & + & + & + \\
Phlobatannins & - & - & - & - \\
Anthraquinones & - & - & - & - \\
Cardiac glycoside & + & - & - & + \\
\hline & & & &
\end{tabular}

Table 2. Quantitative analysis of phytoconstituents in ethyl acetate extract of Cleome gynandra leaves

\begin{tabular}{lll}
\hline S. No. & Phytoconstituents & (\%) \\
\hline 1. & Phenol & 13.9 \\
2. & Flavonoid & 11.94 \\
3. & Alkaloid & 0.064 \\
4. & Steroid & 16.32 \\
5. & Terpenoid & 7.4 \\
6. & Tannins & 5.0 \\
7. & Saponins & 2.3 \\
\hline
\end{tabular}

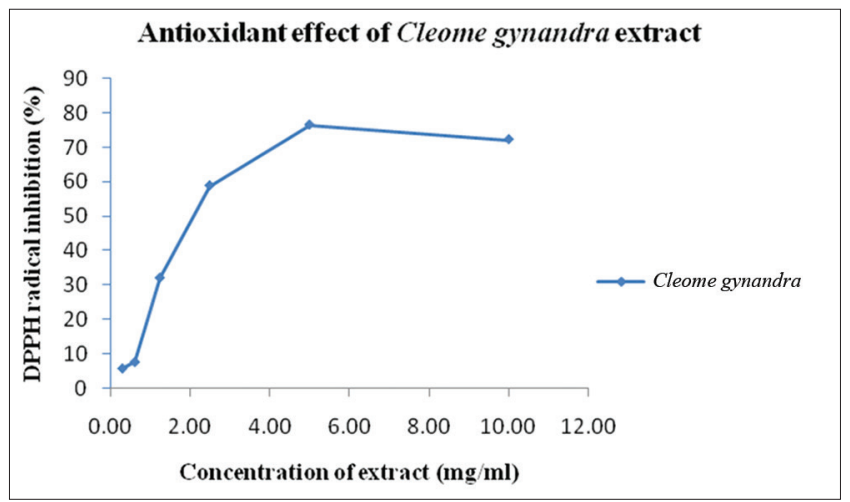

Fig. 1: 1,1-diphenyl-2-picrylhydrazyl radical scavenging of ethyl acetate leaf extract of Cleome gynandra 
$50 \%$ ) as $72.24 \%$. Our results of the DPPH free radical scavenging assay suggested the antioxidant nature of the extract (Fig. 1).

The cytotoxic effect of ethyl acetate extract of $C$. gynandra leaves is represented in Fig. 2 and Plate 1. The potent inhibitory activity $\left(\mathrm{IC}_{50}\right)$ of the plant extract was found to be $90.2 \mu \mathrm{g} / \mathrm{ml}$ against MCF-7 cancer cell line.

Fragmentation pattern of few compounds identified in the selected plant extracts through GC-MS analysis is given in Table 3. Maximum $\%$ of n-hexadecanoic acid has been detected in the leaf extracts of $C$.gynandra and followed by the other compounds were recorded (Figs. 3 and 4, Table 3).

Palmitic acid or hexadecanoic acid in IUPAC nomenclature is the most common fatty acid (saturated) found in animals, plants, and microorganisms [24]. As the name indicates, it is a major component of the oil from palm trees (palm oil), but can also be found in meats, cheese, butter, and dairy products. In this study, we observed the significant cytotoxic effect of the extract on MCF-7 cells. This efficacy might be due to the presence of palmitic acid (n-hexadecanoic acid). Among the chemical phytoconstituents, n-hexadecanoic acid or palmitic acid was found to be more in the leaf extract. Fatty acids can be attributed to the antioxidant activity. Palmitic acid was reported to be a more effective free radical scavenger than $\beta$-carotene [25] besides the palmitic acid, $\mathrm{n}$-hexadecanoic acid present in essential oil may also contribute to the antioxidant activity.

This in vitro cytotoxic observation is in agreement with earlier reports states that palmitic acid (n-hexadecanoic acid) induced apoptosis in the human leukemic cell line MOLT-4. Palmitic acid also showed in vivo antitumor activity in mice. One of the molecular target of palmitic acid in tumor cells is DNA topoisomerase I, [26] however, interestingly, it does not affect DNA topoisomerase II, suggesting that palmitic acid could be a lead compound to develop anticancer drugs. Palmitic acid ethyl esters also possess antioxidant, hypocholesterolemic, nematicide, pesticide, antiandrogenic flavor, hemolytic, and alpha reductase inhibiting property [27]. The phenolic compounds such as gallic acid, protocatechuic acid, p-hydroxybenzoic acid, chlorogenic acid, vanillic acid, syringic acid, catechol, 4-methyl catechol, syringol and pyrogallol, and fatty acids such as linoleic acid, myristic acid, and palmitic acid from the fractions of Polygonum bistorta L. and the fractions were evaluated for their cytotoxic activity on human hepatocellular carcinoma cell line (HCCLM3). These fractions showed good to strong cytotoxicity in the range of $200-800 \mu \mathrm{g} / \mathrm{ml}$ [28].

It has been previously reported that phytol, an acyclic diterpene alcohol, plays a key role in the control of tumor growth by reducing the level of cytokine production and also by preventing the formation of free radicals [29]. Phytol also exhibits antimicrobial, anticancer, diuretic, and anti-inflammatory [30]. In the plant selected for this study phytol was also detected. Further evidence prove that phytol is found to have cytotoxic, anticancer, antidiabetic, lipid-lowering, and aniteratogenic activities [31]

In recent years, plant-derived bioactive substances especially anticancer ones have gained considerable attention [32]. Moreover, many plants containing phenolic compounds have been found to possess good anticancer activity $[33,34]$ and based on this fact plants rich in phenolic content have been considered as interesting in developing anticancer drug $[35,36]$. Phenolic compounds are known to be strong antioxidant compounds with the ability to scavenge free radicals $[37,38]$ and the antioxidant potential of Lonicera japonica essential oil might be due to the presence of high levels of phenolic compounds $[39,40]$. Phenols are present to the tune of $13.9 \%$ in the plant selected for this study. Hence, the antiproliferative activity of $C$. gynandra against MCF-7 cells could also be attributed to the presence of palmitic acid, phytol and phenol probably through apoptosis and free radical scavenging mechanism.

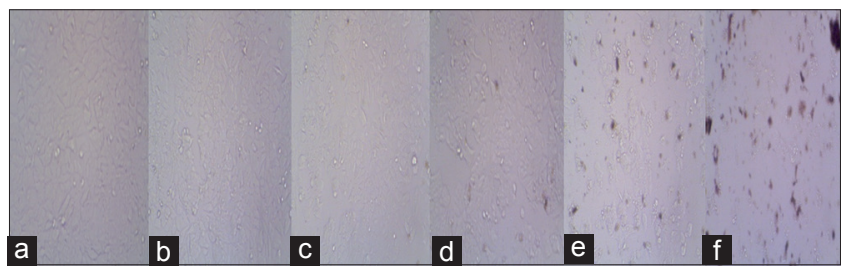

Plate 1: Effect of Cleome gynandra ethyl acetate extract on Michigan Cancer Foundation-7 cell line. (a) Cells with no extract, from (b-f) cells with treated with $12.5,25,50,100$, and $200 \mu \mathrm{g} / \mathrm{ml}$

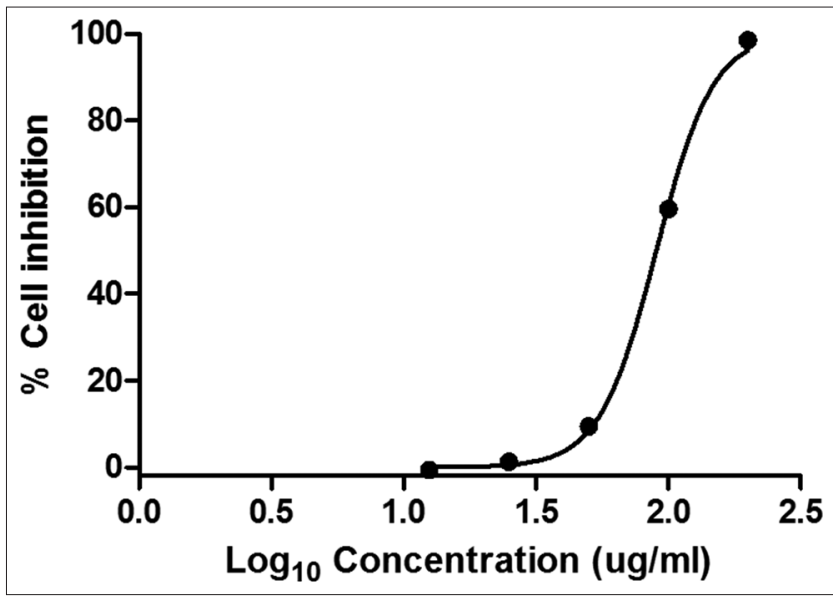

Fig. 2: Cytotoxicity of Cleome gynandra leaf extract on Michigan Cancer Foundation-7 cells

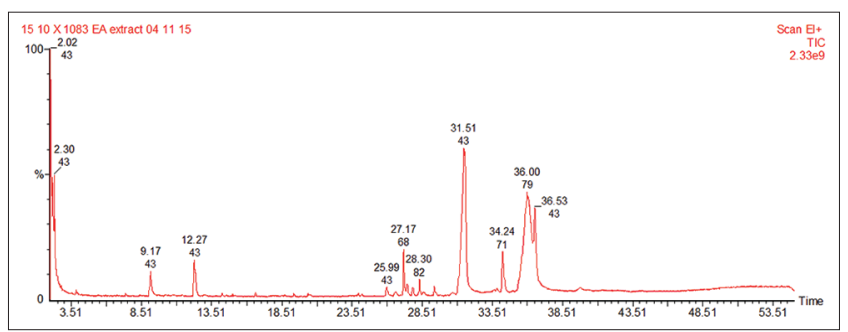

Fig. 3: Gas chromatography-mass spectrometry chromatogram of ethyl acetate extract of Cleome gynandra

Table 3: Identified molecules from the leaves extract of in ethyl acetate extract of Cleome gynandra

\begin{tabular}{|c|c|c|c|c|c|}
\hline Peak name & M.F & M.W & Retention time & Peak area & Peak area $(\%)$ \\
\hline 1,2,3-propanetriol, monoacetate & $\mathrm{C}_{5} \mathrm{H}_{10} \mathrm{O}_{4}$ & 134 & 9.17 & 36455736 & 3.3089 \\
\hline 1,2,3-propanetriol, 1 acetate & $\mathrm{C}_{5}^{5} \mathrm{H}_{10} \mathrm{O}_{4}$ & 134 & 12.27 & 46973656 & 4.2636 \\
\hline 3,7,11,15-tetramethly - 2 hexadecen-1-ol & $\mathrm{C}_{20} \mathrm{H}_{40} \mathrm{O}$ & 296 & 27.17 & 42732324 & 3.8786 \\
\hline n-hexadecanoic acid & $\mathrm{C}_{16}^{20} \mathrm{H}_{32}^{40} \mathrm{O}_{2}$ & 256 & 31.51 & 468538720 & 42.5274 \\
\hline Phytol & $\mathrm{C}_{20}^{16} \mathrm{H}_{40}^{32} \mathrm{O}^{2}$ & 296 & 34.24 & 60032340 & 5.4489 \\
\hline 9,12,15-octadecatrienoic acid & $\mathrm{C}_{18}^{20} \mathrm{H}_{30}^{40} \mathrm{O}_{2}$ & 278 & 36 & 296011136 & 26.8678 \\
\hline 2,3,3-trimethyl-2(4-methylpentanoyl)-cyclopentanone & $\mathrm{C}_{14}^{18} \mathrm{H}_{24}^{30} \mathrm{O}_{2}^{2}$ & 224 & 39.8 & 11550140 & 1.0484 \\
\hline
\end{tabular}




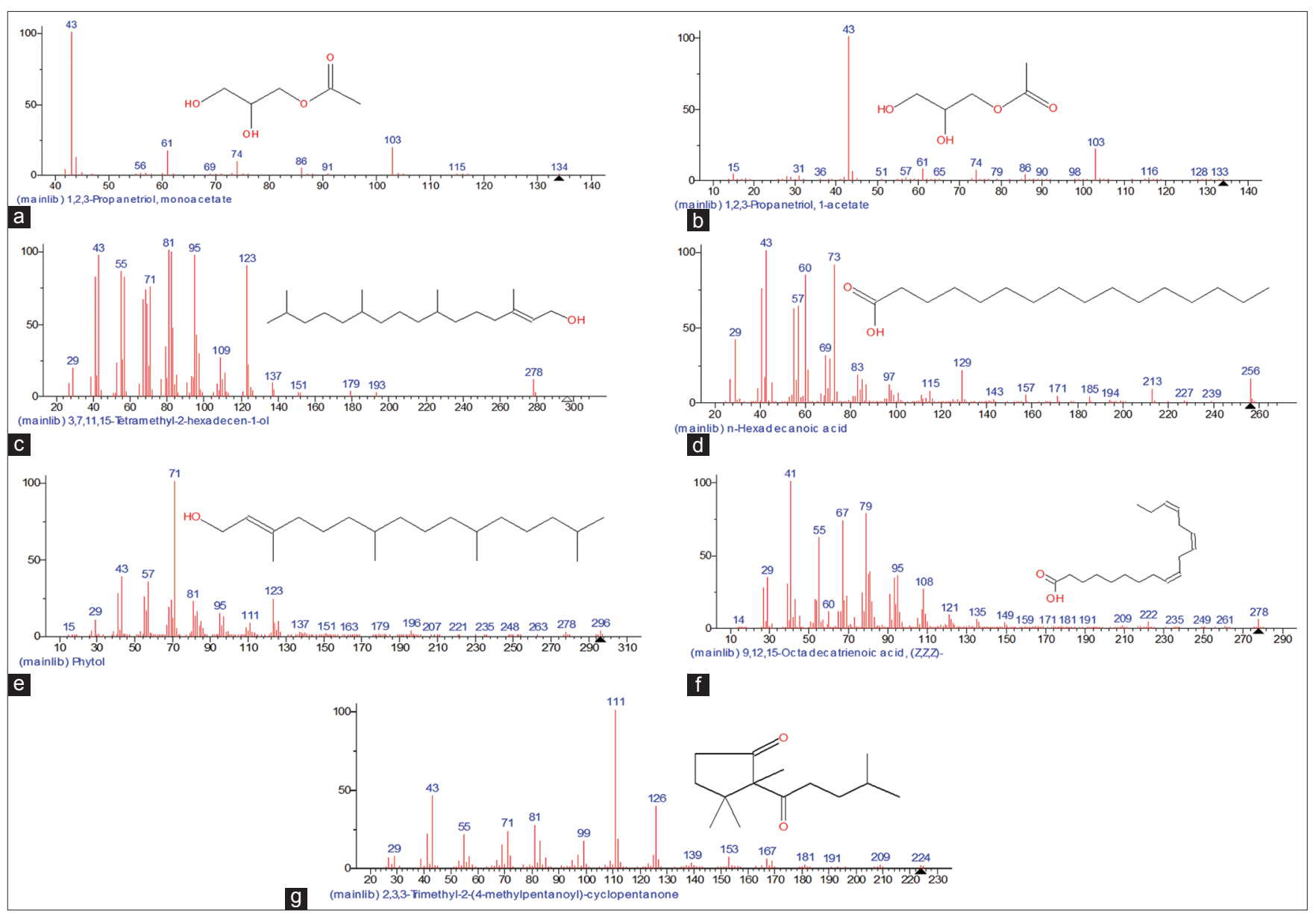

Fig. 4: (a-g) Gas chromatography-mass spectrometry spectrum of various compounds identified in Cleome gynandra

\section{CONCLUSION}

The data obtained through in vitro studies depicted that $C$. gynandra possess significant anticancer and antioxidant activities. Chemical moieties detected in the GC-MS analysis such as palmitic acid, phytol, and phenol further provided chemical evidence for anticancer action of the selected extract. Further studies in this area might help in developing a novel anticancer drug for the betterment of cancer population.

\section{REFERENCES}

1. Umadevi P, Selvi S, Devipriya D, Murugan S, Suja S. Anti tumor and antimicrobial activities and inhibition of in-vitro lipid peroxidation by Dendrobium nobile. Afr J Biotechnol 2009;8(10):2289-93.

2. Abdullah LN, Chow EK. Mechanisms of chemoresistance in cancer stem cells. Clin Transl Med 2013;2(1):3.

3. Liu W, Li SY, Huang XE, Cui JJ, Zhao T, Zhang H, et al. Inhibition of tumor growth in vitro by a combination of extracts from Rosa roxburghii tratt and Fagopyrum cymosum. Asian Pac J Cancer Prev 2012;13:2409-14.

4. Subramaniyan $\mathrm{V}$, Saravanan $\mathrm{R}$, Baskaran $\mathrm{D}$, Ramalalingam $\mathrm{S}$. In vitro free radical scavenging and anticancer potential of Aristolochia indica against mcf-7 cell line. Int J Pharm Pharm Sci 2015;6:392-6.

5. Xu JK, Yuan QG, Luo P, Sun XL, Ma JC. Pleurotus eous polysaccharides suppress angiogenesis and induce apoptosis via ROS-dependent JNK activation and mitochondrial mediated mechanisms in MCF-7 human breast cancer cells. Bangladesh J Pharmacol 2015;10:78-86.

6. Rajendran S, Saravanan R, Ramalingam S, Hameed SA. Antiproliferative and antioxidant activity of Gynandropsis pentaphylla Linn on Mcf-7 cell line. Int J Pharm Pharm Sci 2014;7:561.

7. Nobili S, Lippi D, Witort E, Donnini M, Bausi L, Mini E, et al. Natural compounds for cancer treatment and prevention. Pharmacol Res 2009;59(6):365-78.

8. Govt. of India. The Ayurvedic Pharmacopoeia of India. Part-1. Vol.
1-13. New Delhi: Govt. of India Publication; 1996.

9. Anbazhagi K, Kadavul G, Suguna G, Petrus AJ. Studies on the pharmacognostical and in vitro antioxidant potential of Cleome gynandra Linn. Leaves. Nat Prod Radiance 2009;2:151-7.

10. Makgakga C. Pretoria: National Botanical Institute; 2004. Available from: http://www.arjournals.org/index.php/ijpm/article/view/1325.

11. Harbone JB. Phytochemical Methods: A Guide to Modern Techniques of Plant Analysis. $1^{\text {st }}$ ed. London: Chapman and Hall; 1993. p. 27.

12. Mallick CP, Singh MB. Plant Enzymology and Histoenzymology. New Delhi: Kalyani Publishers; 1980. p. 286.

13. Ferguson NM. A Text Book of Pharmacognosy. New Delhi: Mac Millan Company; 1956. p. 191.

14. Anonymous. Quality Control Methods for Medicinal Plant Materials. Geneva: World Health Organization; 2008. p.48.

15. Obadoni BO, Ochuko PO. Phytochemical studies and comparative efficacy of the crude extracts of some homeostatic plants in Edo and delta states of Nigeria. Glob J Pure Appl Sci 2001;86:2003-8.

16. Kadifkova Panovska T, Kulevanova S, Stefova M. In vitro antioxidant activity of some Teucrium species (Lamiaceae). Acta Pharm 2005;55(2):207-14.

17. Arnab A, Goyal AA, Middha SS. Antioxidant and pharmaceutical potential of Clerodendrum laevifolium. Nat Pharm 2010;1:40.

18. Saravanan R, Pemiah B, Narayanan M, Ramalingam S. In vitro cytotoxic and gas chromatography-mass spectrometry studies on O. Stamineus benth. (Leaf) against MCF-7 cell lines. Asian J Pharm Clin Res 2017;3:1-7.

19. Monks A, Scudiero D, Skehan P, Shoemaker R, Paull K, Vistica D, et al. Feasibility of a high-flux anticancer drug screen using a diverse panel of cultured human tumor cell lines. J Natl Cancer Inst 1991;83(11):757-66.

20. Mosmann T. Rapid colorimetric assay for cellular growth and survival: Application to proliferation and cytotoxicity assays. J Immunol Methods 1983;65:55-63.

21. Balamurugan V, Balakrishnan V, Robinson JP, Ramakrishnan M. Anticancer and apoptosis-inducing effects of Moringa concanensis 
using hepG2 cell lines. Bangladesh J Pharmacol 2014;9:604-9.

22. Narendhirakannan RT, Subramanian S, Kandaswamy M. Antiinflammatory and lysosomal stability actions of Cleome gynandra L. studied in adjuvant induced arthritic rats. Food Chem Toxicol 2007;45(6):1001-12.

23. Chi M, Zhang C, Zheng G, Mei X. Determination of radical scavenger in Chinese drug by spectrophotometry. China J Tradit Chin Med Pharm 2003;8(9):567-8.

24. Gunstone FD, Harwood JL, Dijkstra AJ. The Lipid Handbook with CDROM. $3^{\text {rd }}$ ed. Boca Raton: CRC Press; 2007.

25. Kim S, Jeong S, Park W, Nam K, Ahn DU, Lee S. Effect of heating conditions of grape seeds on the antioxidant activity of grape seed extracts. Food Chem 2006;97:472-9.

26. Harada H, Yamashita U, Kurihara H, Fukushi E, Kawabata J, Kamei Y. Antitumor activity of palmitic acid found as a selective cytotoxic substance in a marine red alga. Anticancer Res 2002;22(5):2587-90.

27. Kumar PP, Kumaravel S, Lalitha C. Screening of antioxidant activity, total phenolics and GC-MS study of Vitex negundo. Afr J Biochem Res 2010;4(7):191-5.

28. Silva RO, Sousa FB, Damasceno SR, Carvalho NS, Silva VG, Oliveira FR. Anti-inflammatory and antinociceptive activity of epiisopiloturine, an imidazole alkaloid isolated from Pilocarpus microphyllus. J Nat Prod 2013;76(6):1071-7.

29. Intisar A, Zhang L, Luo H, Kiazolu JB, Zhang R, Zhang W. Anticancer constituents and cytotoxic activity of methanol-water extract of Polygonum bistorta L. Afr J Tradit Complement Altern Med 2012;10(1):53-9.

30. Suresh KR, Kottaimuthu R, Norman SJ, Kumuthakalavalli R, Simon SM. Medicinal plants used by Malayali tribals in Kolli hills of Tamil Nadu. Int J Res Ayurveda Pharm 2011;2:502-8.

31. Islam MT, de Alencar MV, da Conceição Machado K, da Conceição Machado K, de Carvalho Melo-Cavalcante AA, de Sousa DP, et al.
Phytol in a pharma-medico-stance. Chem Biol Interact 2015;240:60-73.

32. Oueslati S, Ksouri R, Falleh H, Pichette A, Abdelly C, Legault J. Phenolic content, antioxidant, anti-inflammatory and anticancer activities of the edible halophyte Suaeda fruticosa Forssk. Food Chem 2012;132:943-7.

33. Cai Y, Luo Q, Sun M, Corke H. Antioxidant activity and phenolic compounds of 112 traditional Chinese medicinal plants associated with anticancer. Life Sci 2004;74(17):2157-84.

34. Owen RW, Giacosa A, Hull WE, Haubner R, Spiegelhalder B, Bartsch $\mathrm{H}$. The antioxidant/anticancer potential of phenolic compounds isolated from olive oil. Eur J Cancer 2000;36(10):1235-47.

35. Huang WY, Cai YZ, Zhang Y. Natural phenolic compounds from medicinal herbs and dietary plants: Potential use for cancer prevention. Nutr Cancer 2010;62(1):1-20.

36. Vuorela S, Kreander K, Karonen M, Nieminen R, Hämäläinen M, Galkin A, et al. Preclinical evaluation of rapeseed, raspberry, and pine bark phenolics for health related effects. J Agric Food Chem 2005;53(15):5922-31.

37. Soobrattee MA, Neergheen VS, Luximon-Ramma A, Aruoma OI, Bahorun T. Phenolics as potential antioxidant therapeutic agents: Mechanism and actions. Mutat Res 2005;579(1-2):200-13.

38. Ascencio PG, Ascencio SD, Aguiar AA, Fiorini A, Pimenta RS. Chemical assessment and antimicrobial and antioxidant activities of endophytic fungi extracts isolated from Costus spiralis (Jacq.) Roscoe (Costaceae). Evid Based Complement Altern 2015;20:12093-113.

39. Wang $\mathrm{H}$, Gao XD, Zhou GC, Cai L, Yao WB. In vitro and in vivo antioxidant activity of aqueous extract from Choerospondias axillaris fruit. Food Chem 2008;106:888-95.

40. Kunyanga CN, Imungi JK, Okoth MW, Biesalski HK, Vadivel V. Total phenolic content, antioxidant and antidiabetic properties of methanolic extract of raw and traditionally processed Kenyan indigenous food ingredients. LWT Food Sci Technol 2012;5:269-76. 